\title{
Global Mine Productivity Issues: A Review
}

\author{
Jairo Ndhlovu ${ }^{1}$, Peter R K Chileshe ${ }^{2}$ \\ ${ }^{1,2}$ Copperbelt University \\ ${ }^{1}$ Mopani Copper Mines plc - Kitwe Mine Site
}

\begin{abstract}
Global mine productivity issues are of high importance in mining industry and thus, every single effort must be put in place at every mining stage if continuity flow of ore and profitability is to be achieved. Globally mine productivity issues cause production hitches as shown by failure in meeting production targets in the mines. The major global mine productivity problems that lead to instability in sustainable ore production are drilling, stoping, ventilation systems, blasting, rock fragmentation, dilution, haul road /rail track maintenance, ore handling and equipment maintenance. The objective of the paper was to review these mine productivity issues that lead to ore production shortfalls.

The study concluded that in order to improve productivity and production, firstly, supervision of operations and maintenance needs to be well optimised, secondly, technology innovations and enhancement are vital and, thirdly, efficient implementation of strategic and tactical plans is necessary.
\end{abstract}

Key words: 1 Management 2.Supervision 3.Sustainability 4.Productivity.5. Production

\section{INTRODUCTION}

The purpose of this paper was to review global mine productivity issues of relevance to sustainable underground ore production. It highlights existing state of underground mine practices globally. The paper presents qualitative and quantitative literature regarding the effect in mine productivity growth of three important factors, which form the conceptual framework: technical, operations and maintenance (Figure1).

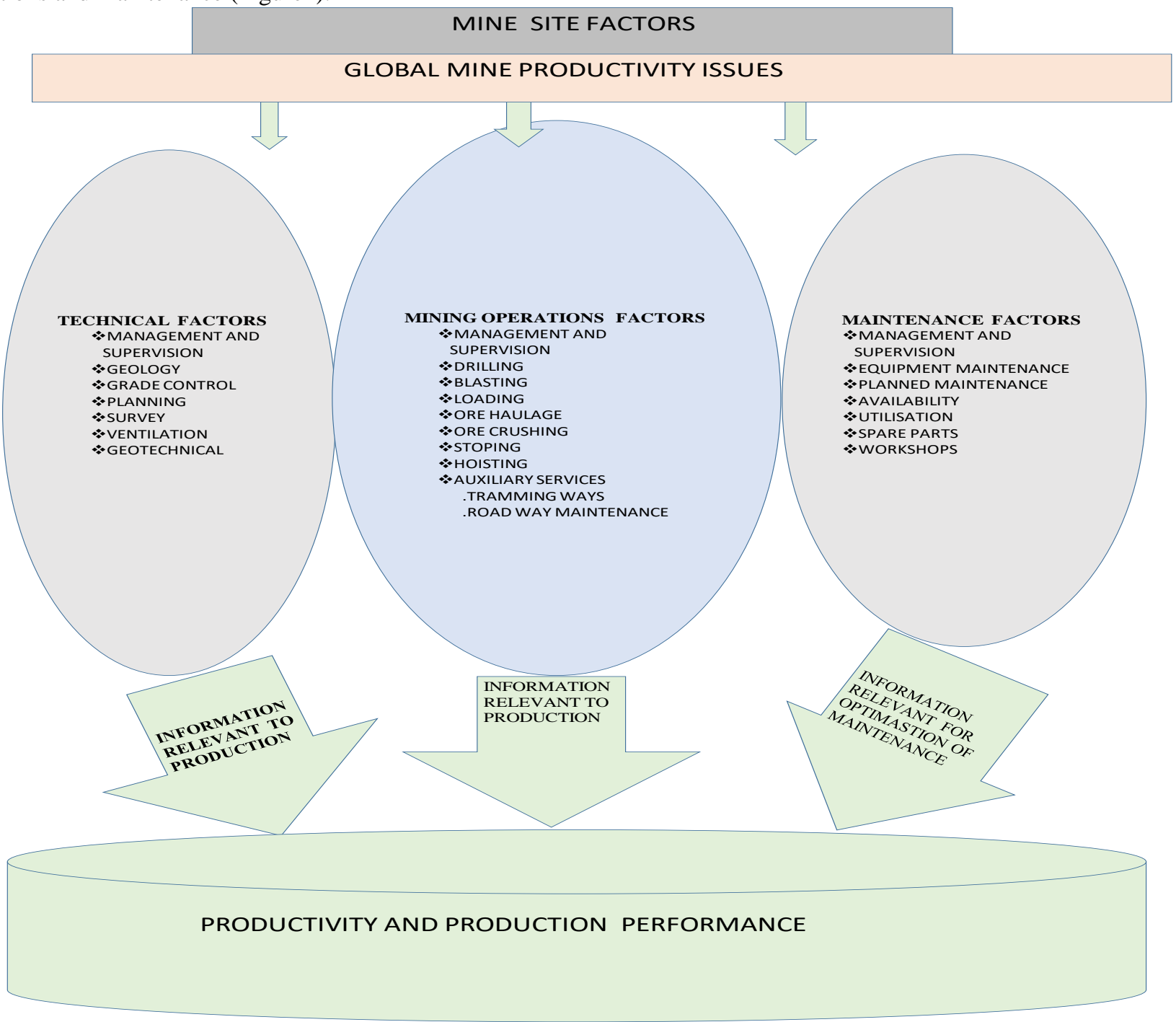

Figure1: Conceptual frame work of global mine productivity parameters 
Generally, the conceptual framework in this study develops a management structure that addresses the research problem and provides stability in productivity and production. From Figure 1, it is seen that technical strategy maintenance policy is strongly tied to production policy and site conditions. Hence, determination of an optimum sustainable mine productivity model needs to account for the effects of all three.

\subsection{THEORETICAL FRAMEWORK}

In general, productivity is a measure of performance or output. It is a measure of how effectively the business targets of mining companies are being met. The main factors influencing productivity are training, experience of the workforce, quality of management, investment in production, technology, equipment, facilities and general level of education. In underground mining, productivity implies the state of being able to generate and enhance ore and through puts. Production is the process of converting any kind of inputs in all mining unit processes to outputs either tangible or intangible.

In the context of mining, drilling is a cutting process that uses a drill bit to make a hole of circular cross-section in into rock mass. The drilling rate of penetration in the rock mass is expressed in metres per hour or per shift. Blasting is a process of breaking a solid rock to fragments by using an explosive, to enable easy handling of material. Conventional blasting operations include (a) drilling holes, (b) placing a charge and detonator in each hole, (c) detonating the charge, and (d) clearing away the broken material. Upon detonation, the chemical energy in the explosive is liberated, and the compact explosive becomes transformed into a glowing gas with an enormous pressure and temperature (Wikipedia, (2020).

The powder factor is a relationship between how much rock is broken and how much explosive is used to break the rock and it is expressed as a quantity of rock broken by a unit weight of explosives. The cycle time in underground mining productivity is broken up into loading time, haul to tip time [loaded], dumping time [queuing], spotting [manoeuvring] time at dumping, tipping time, haul to draw point [empty] time, waiting time[queuing] time, spotting time at loading and the same process starts again repeatedly. These are alternatively broken up into loading and hauling cycle times. For maintenance, availability, utilisation and reliability of equipment and machines are the main productivity drives.

\subsection{METHODOLOGY}

The paper is based on the data collected globally on different mine sites and took into consideration production essentials matching with the productivity of each unit operation such as drilling, blasting, loading and hauling. In order to achieve the objective of the study, the literature review on global mine productivity issues on sustainable ore productivity was categorised into three elements (Figure 1), that is, technical, operations and maintenance.

In the paper, data on global mine productivity issues was done through research work of all relevant information pertaining to the study.These included literature on various mine special reports on drilling, charging, blasting, loading, trackless mobile mining machines $\left(\mathrm{TM}^{3}\right)$ and ore handling as well as maintenance of equipment and machines. Furthermore, other information relating to the same emanated from journals, mining magazines, internet and textbooks.

\subsection{REVIEW FINDINGS}

Globally, all underground mining cycles move in accordance with the innovations in mining equipment, so that mine shareholders maximise profits and productivity. The mining industry is swarming with essential equipment, companies like Sandvik, P\&H, Epiroc, Caterpillar and Atlas Copco have launched some of the most technologically advanced machinery in recent years to improve on productivity and production and the pace is not slackening down. Equipment is smarter, faster, and safer, helping mining companies increase productivity while keeping operational costs at a minimum.

\subsection{TECHNICAL FACTORS IN MINE PRODUCTIVITY}

Globally mine technical sections play an essential role in generating feasible production plans that are in line with the requirements of the operations, for profitability and productivity. The technical group disciplines include geology, mine planning and design, geotechnical engineering, survey and ventilation. Worldwide in all underground mines, strategies for control of input variance and technical decision-making behaviour, has a great influence on mine productivity and production (Whittle, 2018).

\subsubsection{Management and supervision}

In the study, mine productivity issues occur as a result of unbalanced management elements in technical, operations and maintenance activities. Management strategic and supervision decision making affects the productivity and production in mines. This is the first of three functions in underground mine productivity and production. The role of the technical management function is to provide technical expertise and overall management of the technical services in accordance with operational need. The objectives of this function are to plan, implement, and maintain a stable technical supervision to support the business processes of the mines. This encompasses training and deploying appropriate personnel to learn latest software and operate the technology required to deliver and support mine operations. Globally, management is expected to make rapid evaluation decisions at different stages of underground projects based on limited and uncertain data. However, the challenge is to make technical complexity into a financial model usually designed to produce only one or two key indicators, e.g. net present value (NPV) or internal rate of return (IRR) (MacEwan, 2020). 


\subsubsection{Mine planning}

In the paper, mine planning is the progression of thinking about the activities required to achieve an anticipated goal. It is the first and prime action to achieve desired results in sustainable ore productivity and production. It involves the establishment and upkeep of a plan, such as a budget or three year plan. At this juncture, the planning function formulates one or more detailed plans to achieve optimum balance of ore with the available resources. The planning process (a) identifies the goals or objectives to be achieved, (b) formulates strategies and tactics to achieve them, (c) arranges or creates the means required, and (d) implements, directs, and monitors all steps in their proper sequence.

Worldwide, all mining companies need software solutions to accomplish exploration and production of minerals, enhance the use of human resources and equipment, and conform to statutory environmental, health, and safety guiding principles. Mining software are used to approximate the mineral deposits by modeling, managing the infrastructure desirable for ore extraction or track the mining and fragmentation of ore throughout the mining cycle.

Extensive investments in mining projects require diverse use of dissimilar type of software to lower expenses for equipment repairs, production and to ensure the efficiency of personnel. They also help to provide the necessary technical information for survey, geology, ventilation and rock mechanics. Some mining software solutions focus on exploration and production, whereas others provide only features for asset maintenance, and are discussed below.

\subsubsection{Micromine 2020 mining software}

The launch of MICROMINE's latest version of leading exploration and 3D mine design solution, introduce stope optimisation functionality. The new version of Micromine not only includes innovative upgrades to current modules, but also sees new functionality included in response to mining industry needs. The module specifically caters to the needs of underground mine planners looking to optimise mine design to ensure project profitability. Micromine 2020 provides an equivalent strategic planning tool for underground mining operations and its optimiser use integrated mathematical programming to produce optimum 3D solutions. Stope Optimiser identifies regions within a resource model mined profitably using designs for a range of potential stoping methods and assists mine planners in selecting the most profitable combination of method, stope design and mine life. It is suitable for all planning horizons, and generates the best possible stope outlines that satisfy design and economic parameters (Micromine, 2020).

\subsubsection{Geology}

In any mining operation, understanding the geology of the orebody and waste rocks is fundamental for successful resource estimation and the development of a defined mineral resource. As a result of this information, a plan for the extraction of a wellblended mixture of low and high grade ores can be made. This planning ensures that the mining process is prolonged, the removal of ore is optimised and the metallurgical processing plant, which will not work well if there are large grade variations, is able to operate economically and at consistently high levels of efficiency. The most common parameters influencing dilution and ore losses in underground mining are (a)Orebody delineation (b)Design and sequencing (c)Stope development (d) Drilling and blasting (e) (f)Production, and mine management issues (Lappalainen, 1996).

\subsubsection{Geovia Surpac}

Geovia Surpac is a very popular geology and mine planning software, supporting underground operations and exploration projects in more than 120 countries worldwide. The software provides efficiency and accuracy through powerful 3D graphics and workflow automation that can be aligned to company-specific processes and data flows. Surpac addresses all the requirements of geologists in the resource sector as well as surveyors and mine planners and is flexible enough to suit every orebody and mining method. Its capabilities allow global companies to support a common solution across their operations (Geovia, 2020).

\subsubsection{Pitram grade control software}

In all mines grade control provides an overview of the issues influencing dilution in an underground production environment. Pitram's mining grade control software utilises mine design, survey and production data to provide real-time stockpile balances and metal stocks throughout the mining operation to assist with the accuracy of grade control. Grade control is critical to practical excavation plans. Any inaccuracies at this stage can cause major setbacks to operational and business performance. During exploration, grade control is a mining process to quality check and control the grade and variability of an ore. The purpose of grade control is for mining companies to understand and document any variability in their sampling and their ore reserve (Micromine, 2020).

\subsubsection{Ventilation}

Ventilation in the study is among the most important functions in a mining operation. It provides a sufficient flow of air to dilute and remove dust and noxious gases and to regulate temperature to all underground working places and travel ways. The major sources of these gases are personnel, equipment that runs on diesel engines and blasting with explosives.

\subsubsection{Arctic Vent Control system}

Arctic Vent Control is ventilation on demand system that provides full control over airflow within the mining site. This advanced mine ventilation system has vehicle detection, gas detection, air quality sensors and scheduling possibilities that optimises the airflow underground. The ventilation system works independently and does not require any infrastructure in the 
form of Wi-Fi or other IT solutions. Due to its independence, Arctic Vent Control is easy to install and requires low initial costs. The system is also scalable, and each fan control unit is autonomous. That means the ventilation system, can be installed, and tested in one small part before continuing with installations throughout the mine. Globally, ventilation directly affects the health and safety of employees working underground, it is therefore, imperative to take the regulation of airflow through a mine very seriously (Gefasystem, 2020).

\subsubsection{Survey}

Mine surveying determines the relative positions of points on or beneath the surface of the earth by direct or indirect measurements of distance and angles. It is responsible for maintaining an accurate plan of the mine as a whole and updating map of the layouts to account for new underground excavations and keep records of the mining operations. More importantly, the surveying is involved in the measuring process to calculate ore production, in volume or mass units, from the mining operation. In addition to this, the volume of the waste backfilled in the VCR stopes.

\subsubsection{Amine data mine AutoCAD software}

The most progressive AutoCAD-based mine design software called Amine is the perfect tool for all underground mine surveyors. It includes a comprehensive suite of underground surveying tools including a laser offset function, automated cavity monitoring systems (CMS) slicing and underground monthly reporting summary. It simplifies and updates daily survey tasks whilst providing a more effective and timesaving reporting process. The software provides automated workflows that align with mines current productivity processes and needs. It is flexible enough to be used for any ore body and mining method (Datamine, 2020).

\subsubsection{Geotechnical}

Globally, the purpose of geotechnical engineering is to provide ground stability and support information to maintain excavation safety and access for their intended lifespan. The effectiveness of a support strategy is important for two main reasons, namely; safety to personnel and equipment, and to achieve the most economical extraction of ore. The type of ground support required in a particular location is dependent on several factors including the rock mass strength, the geometry of the excavation, the induced stresses, the blasting practices and the weathering process.

The control and management to address the risk of ground/strata failure is achieved through taking into account geological/geotechnical considerations in the mine design and planning processes and determining stresses with the aid of latest soft wares. Worldwide, this is achieved, among others, through gathering geotechnical data underground during site visits and routine underground visits by geotechnical engineering personnel. The undertakings include:

- $\quad$ Measuring support distances and compliance to the standard;

- $\quad$ Measuring excavation sizes and compliance to the standard;

- $\quad$ Measuring support to face and sidewall distances;

- $\quad$ Damage mapping;

- $\quad$ Recording information on support installation quality;

- $\quad$ Recording information on blasting compliance;

- Recording general ground conditions;

- $\quad$ Recording information on prominent geological features; and

- $\quad$ Orientation of prominent structures.

\subsubsection{Carlson software -SDPS}

SDPS calculates ground deformations subsidence, strain, horizontal displacements and slope, based on the mine plan and geological characteristics. SDPS is a package developed through the Virginia Polytechnic Institute and State University (Virginia Tech) and Carlson Software is the world's only distributor. In this respect, all programs entirely use the central management of computer resources i.e. memory, use of the clipboard, peripherals. The package is designed to provide an integrated approach to the following problems (Carlson software, 2019)

- Calculation and prediction of ground deformations above undermined areas based on empirical or site-specific regional parameters, the operator can calculate a variety of ground deformation indices according to the profile function method as well as the influence function method. The results are plotted using the graphing program provided, or exported to other graphing programs.

- $\quad$ Calculation of pillar safety factors for room-and-pillar.

\subsubsection{Geotechnical software GE05}

GEO5 is a software package that provides solution for majority of geotechnical tasks. Individual programs have the same user interface and communicate with each other, while each program verifies definite structure type. It enables drawing lines, curves, objects and descriptions on the program desktop, allows to add users dimensions by snapping on the structure and able to create cross sections without need for any other CAD program (Fine software, 2020). 


\subsection{OPERATIONS FACTORS IN MINE PRODUCTIVITY}

Globally, mine operations are vital in mining unit processes tactically in the forefront of productivity and production. The unit processes in mine operations determine economic viability of the whole operation.

\subsubsection{Management and supervision}

Operations management and supervision is mainly concerned with planning, organizing leading coordination and controlling in the contexts of productivity and production.

It is delivery-focused; ensuring necessary improvements for higher profitability and that mines successfully turns inputs to outputs in an efficient manner. The inputs could represent anything from materials, equipment and technology to human resources such as staff or workers. The adjustments in the everyday operations have to support the company's strategic goals. There are five major groups of activities performed by operations management, deriving from its planning, organising leading coordination and controlling role. Activities involve considering assets, costs and human resources (Cleverism, 2018).

\subsubsection{Drilling}

The study looked at the current equipment drilling rate and operational issues at various mines based on drilling achievement. The process involved enquiry of use of modern equipment in production areas and latest technologies used in drilling rig operation that nurture general mine productivity outcomes. The research also evaluated the reasons why modern rigs are more proficient and effective as regards to where the mining business is headed in the future.

\subsubsection{Epiroc DF30-1BCDL drill rig}

DF30-1BCDL drill jumbo used by Zublin International in Chile, which works, as a contractor for the state owned mine is one of innovative high technology rig in underground mines. This equipment uses all hydraulic drive, with high effectiveness and speediness, which can drill $0.8 \mathrm{~m} / \mathrm{min}$ to $2.5 \mathrm{~m} / \mathrm{min}$. The advanced hydraulically well-ordered drilling system, which is easy to maneuver, incorporates the auto stop and anti-jamming function, auto-stop at end-point, auto wash. The rig has a minor frame, runs with the wheels, can reach a speed of $8 \mathrm{~km} / \mathrm{h}$ functioning by electric motor. It also reduces noise, dust and energy consumption on the machine. The rig works on the section, roof, side and floor. The machine cannot only drill blast holes, but also do support in excavations (Epiroc, 2017).

\subsection{2 .2Epiroc viper 351 drill}

Globally, Epiroc viper 351 drills are used in deep and broad of range excavations. In a bid to improve the operator productivity in the work place, increase utilisation and meet drill production goals, Aitik copper mine owned by Boliden in northern Sweden introduced a concept to trial electric autonomous blast hole drilling. The trial started in April 2017 and completed in March 2019. The initial part required tele-remote drilling and the results set the benchmark for phase 2 . The third phase assessed the degree to which the entire design could be drilled with an electric autonomous drill. For the comfort of operator, four cameras are positioned on the rig to enable the operator to have a complete overview of what is happening around the drill. A laser-based system for hindrance detection and a nearness detection solution are also features intended to spot personnel around the machine; this needs staff to put on a tag that vibrates when entering the drill pattern. Aitik Mine is at present successfully achieving 30\% increase in productivity compared to the manned equipment. Generally, drilling is the most critical aspect of achieving good advance in development ends and if it is not done well then any attempt to improving results by changing other parameters will be wasted. When drilling blast holes there are three factors of critical importance: drilling angle, length of drill hole and drilling direction (Epiroc, 2017).

\subsubsection{Charging and blasting}

Currently, worldwide, charging is mostly done by using mobile charging units utility vehicles (UVs) which carry emulsion and supplied by a number of mining corporations such as SASOL, AEL, and BME. This report looked at a new concept in perimeter control blasting for underground metal/nonmetal mine development and production areas with emphasis centering on the status of holes in a blast design.

Daunia coalmine in Queensland, Australia, lately broke the global record for the biggest electronic detonator blast ever, firing 5665 detonators in 2683 blastholes, using BME AXXIS digital detonation system. The blasting crew used BME's blast design software, BlastMap III. The software works in conjunction with the AXXIS Initiation System. The package enables intricate timing designs and analysis of the results for each blast. The advantage of the software is that it is easy to time the blasting designs, which can then be transferred directly to the detonators. This put results in a huge advantage in eradicating timing application faults, consequently eliminates high costs. BlastMapIII also has progressive design features that permit for thorough hole locating and charging thus allowing easy modelling of blast results. It also enables complex huge blasts designs and projecting of vibration, fragmentation and burden relief. At the same mine, another effective controlled blast design using string loading was used as a foundation for analysis using the buffer row concept. The blast reflected a successful design because the designed limit is equal to the drilled limit and the built limit (Daunia Coal Mine, 2019). 


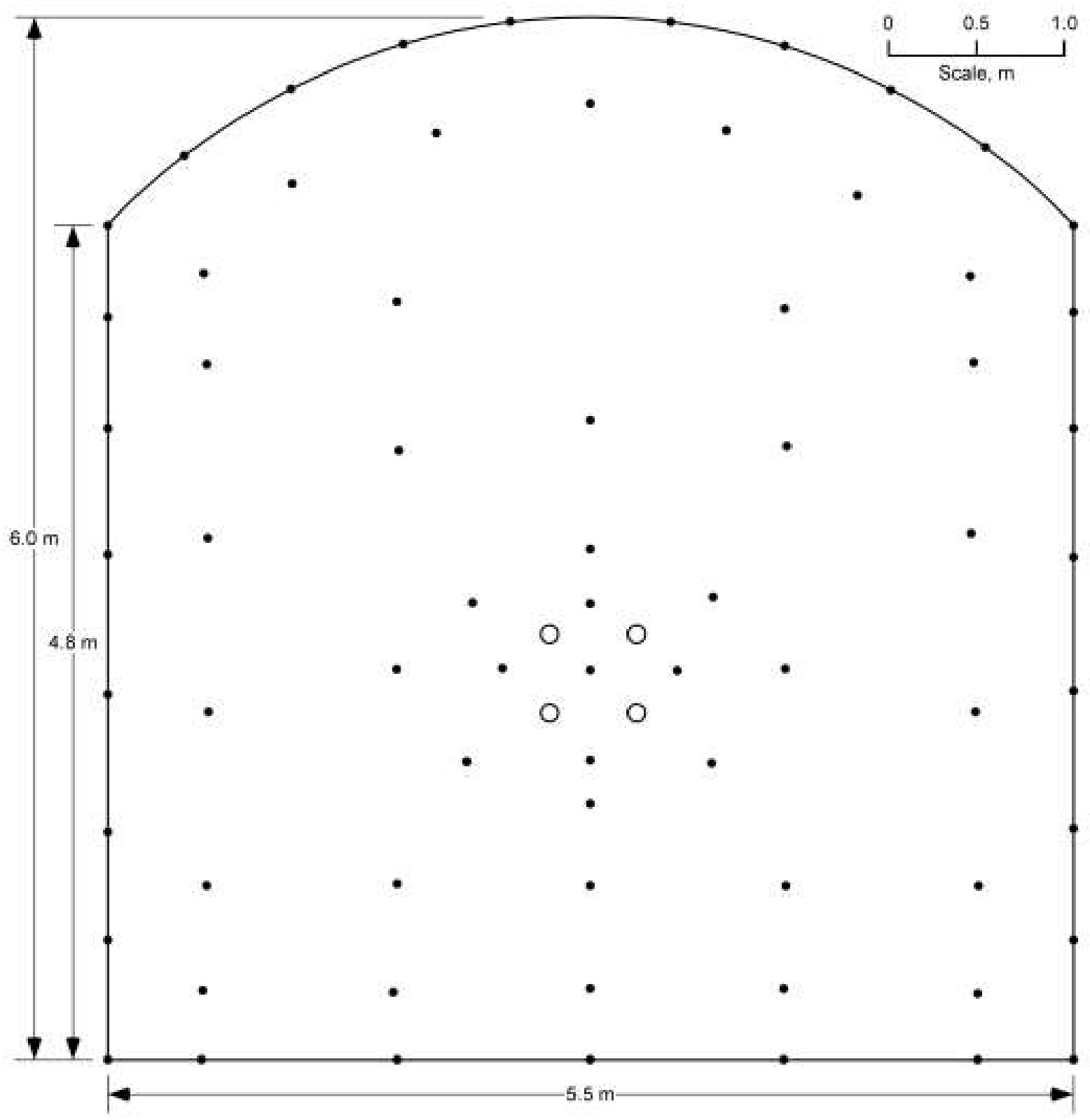

Figure 2. Blast design in Australia that practices string-loaded emulsion (Iverson, 2013).

Figure 2 displays an example of drill hole locations of a positive blast design in Queensland Australia that uses string-loaded emulsion. The round was drilled using a computer-controlled drill jumbo and charged using site-sensitised emulsion. The explosive properties include energy at $3.1 \mathrm{MJ} / \mathrm{kg}(740 \mathrm{kcal} / \mathrm{kg})$, volume at about $950 \mathrm{~L} / \mathrm{kg}$, density at $0.85 \mathrm{~g} / \mathrm{cm}$, VOD equivalent to $4,300 \mathrm{~m} / \mathrm{s}$, and relative weight strength (RWS). The buffer holes were entirely charged and the perimeter holes were string loaded to $50 \%$ of the whole cross-sectional area (0.034 $\mathrm{m}$ in diameter).

\subsubsection{Fragmentation}

Globally, blasting is one of the key components of mining activities and its significant outcome is fragmentation. Fragmentation is the first result of blasting that is directly related to the mining costs. The effective utilisation of the loader is assisted by employing optimised blasting practice i.e. blasting or degree of fragmentation of the in situ rock should be in such a way that loader buckets should not have difficulties in grabbing the blasted material or ground. Unfortunately, in the research it was observed that in some areas loaders more often than not grabs the problematic blasted material such that production has to standstill or delayed. The poor rock fragmentation occurs as a result of either poor drilling practice or poor blasting practice or both.

\subsubsection{Stoping}

Globally, stoping is the process of extracting the desired ore or other mineral from an underground mine, leaving behind an open space known as a stope. It is used when the rock is sufficiently strong not to collapse into the stope and is practised in 
underground mineral mining when the surrounding rock is strong enough to permit the drilling, blasting, and removal of ore without caving, although in most cases artificial support is also provided.

As mining progresses, the stope is often backfilled with waste rock materials. Stoping is considered "productive work", and is contrasted with "dead work", the work required merely to access the copper ore deposit, such as levels, VCR and/SLC chambers.

In this paper, it is noted that a number of mines use different mining methods depending on the size and shape of the ore body i.e. Chibuluma mines practice open stoping, room-and pillar due steeply dipping ore bodies having reasonably firm ore. Caylloma Mine in Peru uses cut-and-fill mining method, which is applicable in the mining of steeply dipping orebodies in stable rock masses. Canadian mining company (INCO) use VCR and is used all over the world in areas with competent, steeply dipping ore and host rock (Goel, 1988).

\subsubsection{VCR stope development}

Productivity of a stope in a VCR mining is directly related to the stope size. Large stopes have high tonnages that can support high mucking rates for long periods of time, resulting in higher productivity rates.

The Homestake mine in South Dakota, North America is a VCR mining operation. Their switch from cut and fill to VCR mining has been a major factor in their increased productivity since the 1970s. The next best method employed at Homestake is mechanised cut-and-fill (MCF), which has proven to be at a $48 \%$ cost disadvantage to VCR, in terms of direct mining costs. The cost advantage is mainly contributed towards higher productivity and less required ground control. The productivity of a mining method will vary based on the dimensions of the orebody, however if the orebody meets the requirements, then VCR mining will provide high productivity rates, when compared to other methods. VCR drilling rigs originates in many shapes, extents and models, manufactured by various companies such as Atlas and Sandvik.

\section{In-The-Hole (ITH)}

The design goal of ITH machines is to make the most of ore extraction and lessen dilution with precise drilling of production holes according to the plan. The ITH drilling is popular for production drilling in open stoping, because of its productivity, and straight hole accuracy. Its technology can be used for drilling up holes and down holes. Features are reliable design with superior fatigue resistance, leading to longer service life and lower operating costs. In Canada, these machines are furnished with a powerful hydraulic rock drill, as well as a carousel storage for extension rods. In addition, drilling can be performed by remote controls, so that the operator may remain in a safe position can also be used for the blastholes, which operate by breaking the hard rock into small flakes and then blowing them clear using an exhaust system (Sandvik, 2016).

The characteristics of the machine were that it was using hydraulics to drill down the hole at a drilling diameter of $165 \mathrm{~mm}$ and depth of $54 \mathrm{~m}$ between the drilling and receiving chambers. The drill is the energy source and prime mover, which converts energy from its original form (fluid) into mechanical energy to trigger the system. The rod conveys the energy from the drill to the bit. The bit then attacks the rock mechanically to attain penetration. Compressed air is the flushing medium in the DTH system. For downward drilling, gravity tends to pull the cuttings towards the bottom of the hole. This is why it is essential to offer annular velocity greater than the slip velocity, to be able to remove cuttings.

Generally, the drilling chambers in which these machines are being operated tend to be quite hot as drilling progresses; this is due to the drilled holes that act as an access for hot air from the extraction level below that is not ventilated. Therefore, it is necessary to cover the holes after drilling. The utmost distress is the premature failure of the roof in the drilling chamber which can be caused by poor drilling of support or the size of the excavation. This could cause damage to the machine and fatality to the men working in the area. Some of the hazards related with working with the DTH machine was the compressed air pipe, which if not handled with care during oil checks could cause harm.

\section{Cybermine DR580 drill rig simulators}

Drill rigs are intricate machines and vital devices in mining operations. The drill rig simulators precisely imitate aspects such as drill length and percussion and train operators to use the machine safely and productively. Safety and efficiency on a mine site is of supreme importance and these training simulators are vital tools in ensuring this is achieved. Training is done without the mine having to take an actual rig out of production for too long as increased availability of the drill aids cost efficiencies. A drill rig from any original engineering manufacturer (OEM) can be simulated, including Atlas Copco, Caterpillar, P\&H and Sandvik (Sandvik, 2019).

\subsubsection{Sub-Level Caving (SLC)}

In the study, universally, sublevel caving (SLC) adapts to large ore bodies, with steep dip and continuity at depth. Sublevel footwall drifts have to be stable, requiring occasional rock bolting only. SLC extracts the ore through sublevels, which are developed in the orebody at regular vertical spacing. Each sublevel features a systematic layout with parallel drifts, along or across the orebody

Drilling jumbos are used for drifting sublevels where as long hole drills are used for fan holes. The drilling is done as a separate operation, well before the blasting. Several sublevels can be drilled well before the blasting and loading starts.

Trackless Load-Haul-Dump (LHD) units are used for loading and ore handling. In SLC, ore extraction normally retreats along a nearly straight front, meaning that the adjacent drifts are operated on simultaneously. 


\subsubsection{Sublevel stoping (SLOS)}

Sublevel open stoping is a highly mechanised mining method utilising a wide range of equipment for drilling and mucking. Typically, high-efficiency column and arm longhole drills or DTH drill rigs carry out production drilling. These systems use electric drive instead of hydraulic and have high-pressure pneumatic DTH hammers or rotary percussion drilling systems. It is with these recent advantages in drilling technology that these systems have transformed sublevel stoping operations.

\subsubsection{3 .1 DL432 long hole up holes drill rig}

Sandvik DL432i is a fully-mechanised, very adaptable and compact electro-hydraulic top hammer long hole drill. It is designed for underground up holes operations and larger production drifts. The advantages of the rig include (Sandvik. 2018):

- $\quad$ Good drilling capability and outstanding control with the latest drilling system components;

- $\quad$ Flexible boom type with good coverage and reach for wide range of applications;

- $\quad$ Automated drilling, data transmission and remote control ensure improved drilling productivity;

- $\quad$ Very comfortable and user friendly operator's safety cabin; and

- $\quad$ Easy access to service points from ground level for safe and fast maintenance

\subsubsection{Ore handling}

Worldwide, mines have different operation systems in accordance with the evolution of equipment, the systems and method of mining. The underground transport system of ores, materials, equipment and persons is cardinal and of critical importance in ore sustainable productivity. Underground ore tends to be very heterogeneous, the largest lumps often being over $1.5 \mathrm{~m}$ in diameter. The broken ore from the stopes, after blasting, is tipped into ore raises. In some mines it is loaded directly into trucks, holding up to $10 \mathrm{t}$ of ore in some cases, and is transported directly to the primary crushers.

Material handling can be complex for underground mining operations. The goal of mine haulage systems or material handling systems is to move rock masses from one location to another in the most efficient way while maintaining production rate and minimising operating costs. With many mining methods, structure, distances, and changing faces or draw points, it is important to understand appropriate material handling systems. These may include conveyor systems, locomotive tramming, scoop tram to trucking, and scoop tram from draw points to ore tips.

\subsubsection{Loading cat 3000H LHD}

A latest load haul and dump truck, also recognised, as scoop tram, is a machine used for loading and for applications in the mining business. Load, Haul and Dump trucks abbreviated LHDs, are used for operations in extreme conditions and are extremely rough, maneuverable and efficient. LHDs are accessible in scope of a hauling limit. Like the majority of the underground mining hardware, the structure of LHD is separated into two sections for improved distribution of weight amid activity. Its development with small height and width and long length encourages giving enhanced mobility to LHD in restricted passages.

The new CAT 3000H LHD offers an increase in truck loading capacity, enhanced digging and breakout performance, faster speeds on grade, a reinforced front frame, and an available ventilation reduction package that lower both machine and mine operating costs (Caterpillar, 2019).

\subsubsection{Dump trucks:}

The paper noted that mining trucks keep on getting better and bigger, as miners progressively opt for huge capacity trucks with greater operational efficiency. Latest dump trucks include the following.

\section{Belaz 75710}

Recently launched, the Belaz 75710 is by far the world's largest underground dump truck, with the capacity to haul an amazing 496 tons of payload. The Belarusian Company Belaz launched the ultra-heavy dump truck in October 2013. The truck is 20.6 metre long, 8.16 metre high and 9.87 metre wide. The empty weight of the vehicle is 360 tons. Belaz 75710 features eight largesize Michelin tubeless pneumatic tyres and two 16-cylinder turbocharged diesel engines. The power output of each engine is $2,300 \mathrm{HP}$. The vehicle uses an electromechanical transmission powered by alternating current. The topmost speed of the truck is $64 \mathrm{~km} / \mathrm{h}$ (Wikipedia, 2019).

\section{Caterpillar 797F}

Caterpillar 797F, the latest model of 797 class dump trucks manufactured and developed by Caterpillar, is the second-biggest mining dump truck in the world. The truck has been in service since 2009. It can carry 400 tons of payload likened to its predecessor models 797B and the first generation 797, with payload capacities of 380 tons and 360 tons respectively. The dump truck has a gross functioning weight of 687.5 tons and measures $14.8 \mathrm{~m}$ in length, $6.52 \mathrm{~m}$ in height and $9.75 \mathrm{~m}$ in width. It is equipped with six Michelin XDR or Bridgestone VRDP radial tyres and Cat C175-20 four-stroke turbocharged diesel engine. The single block, 20-cylinder engine offers a gross power output of up to 4, $00 \mathrm{HP}$. The truck uses a hydraulic torque converter transmission and runs at a top speed of $68 \mathrm{~km} / \mathrm{h}$.

Generally, smaller dump trucks are a common mode of haulage in underground mines and often present within mines that are relatively shallow with ramp access. Hauls trucks are often favoured in mines because of the relatively low capital cost 
associated with them and the high flexibility in routing and capacity. However, haul trucks do incur high operating costs due to fuel consumption, maintenance, noise, heat, ramp traffic, and toxic emissions (Caterpillar, 2019).

\subsubsection{Underground locomotives}

For the paper, a review of locomotives was done so as to appreciate global operation of locos in underground mines. Furthermore, to find out the fill factor, daily targets, inquire on significant risks associated with operating the locomotives.

\subsubsection{Electric mining locomotive}

El Teniente underground mine in Chile use electric mining locomotives, fitted with four independently driven axles. The traction converter controlled travel motors allow the individual torque control of each drive axis. A highly efficient slip and slide protection system guarantees the optimum use of the available traction forces depending on the friction coefficient of the wheel-rail. The locomotive travels along tunnel sections that are completely automated with the help of an automatic train operation system via a serial interface of the locomotive control. At present, drivers control most of the electric locomotives used in the underground rail transportation. Reliability, efficiency, and safety are the common requirements for the underground ore handling (Armbrust et al, 2005).

\subsubsection{Ore crushing}

Ore crushing is done at different depth level by primary crushers; in some mines secondary crushing systems are put in place to further reduce the ore sizes. Crushing of such ore is not always attainable, due to its "long-ranged" particle size, which causes difficulties during crushing, the fines working their way down through the voids between the larger particles; extremely coarse ore is sometimes difficult to handle and cause choker block in the ore stream.

At Caledonia gold mine in Zimbabwe, broken ore is trammed along the 22 level rail system by battery locomotives and the ore cars trains are self-tipped onto one of three grizzlies above the ore bins, which are located between 22 Level and the 765 meter level crushing station. The minus $300 \mathrm{~mm}$ rock is held in three underground storage bins, payable ore and waste ore are held in separate storage bins and handled accordingly. Ore is gravity fed from these ore bins onto the 765 metre level crushing station conveyor, which discharges the ore onto a vibrating grizzly feeder, which discharges the oversize into a $30 \times 20$ Telsmith jaw crusher. The underground crushing station ensures that all the run-of-mine ore is reduced to minus $150 \mathrm{~mm}$ in size as this provides for the optimisation and greater efficiency of the automated skip loading and hoisting operations. This allows mining and hoisting activity to continue without interruption (Caledonia mining, 2020).

\subsubsection{Hoisting}

Generally all mines worldwide, the hoisting system is essential for the transportation of equipment, personnel, mined ore and, thus, for the productivity of the mine. It consists of various components in which there are winders, ropes and electric motors. The safety and reliability of the hoist depends on its design, therefore proper and accurate design of a hoist is essential. For this paper, the review of the design of the components making up the hoist was done through literature review of the hoisting systems, at various mines. A cost effective hoisting system is a great call for all mines to enable ore handling from the section. With mining increasingly becoming a main contributor to economy, it has become necessary to improve mining to yield greater hoisting benefits.

Regionally, Blanket No. 4 Shaft has been equipped with the first automated loading system in Zimbabwe, which sequentially fills the two six tons ore skips which are hoisted from the 789 metre level to surface. The use of this state of the art automation reduces the risk of ore loading accidents and injuries, and also reduces manpower costs, minimises spillage, reduces skip loading times, increases hoisting capacity, ensures precise ore tonnage accountability, and enhances winder efficiency while lowering loading and hoisting costs (Caledonia mining, 2020).

\subsection{MAINTENANCE FACTOR IN MINE PRODUCTIVITY}

The purpose of this paper is to shed light on the various underground maintenance activities and review the gaps between maintenance and operations. Maintenance section is the discipline that apply engineering concepts for the optimisation of mining equipment, procedures, and machinery budgets to achieve better maintainability, dependability, and availability of equipment.

\subsubsection{Management and supervision}

Generally, a maintenance process of equipment in all mines is important in maintaining reliability and availability concerning productivity and production. Maintenance decision make a direct impact on the economic aspect of the mines. Therefore, there is need for supervisors to lead an excellent upkeep of maintenance sections using planning and scheduling, best practices to drive work execution, and motivational and time-management techniques to improve maintenance worker productivity. Globally, to have a good equipment maintenance policy, developing an effective program for managing assets, action plan for managing human capital such as thriving to improving staff motivation, lower employee turnover, increased output and reduced waste of resources is vital (Life cycle engineering, 2020) 


\subsubsection{Equipment maintenance}

Globally, proper machine maintenance in mine productivity is very important as it can ensure success of production. For efficient operation, in all mines certain key elements must be ensured (Granseberg, 2015):

- $\quad$ Competent operators;

- $\quad$ Knowledgeable service members and mechanics;

- $\quad$ Planned service operation;

- Timely spare parts and components; and

- Quality service work.

These elements can be achieved through service support and management. The maintenance of mobile equipment and fixed plant is a major factor and all maintenance should be planned to ensure high productivity with low breakdown time. Worldwide all mines maintenance depends upon:

- $\quad$ Age and condition of machinery;

- $\quad$ Care of machinery by the operator;

- $\quad$ Labour and overhead costs;

- Availability of spares; and

- General maintenance, which includes - lubricants, batteries, tyres, tracks, hydraulics, replacement of ropes all of which should be planned.

Generally, although the main limitation appeared to be due to lack of spares, up-to-date training of staff could improve the maintenance of equipment in productivity and production. This could enhance the planning of maintenance. In the improvement of the operations in the workshop, the upgraded maintenance system should be adopted to enhance overall awareness and importance of maintenance as well as the well-being of the mining companies.

\subsubsection{Machine availability}

Machine availability in mine productivity is the percent of the period that production equipment is available for use, divided by the maximum time it would be available if there were no downtime for repair or unplanned maintenance. It is the actual time that the machine or system is capable of production as a percent of total planned production time (Clarity visual management, 2020).

\subsubsection{Machine utilisation}

Utilisation is a degree of how intensively a machine is being used in productions areas. It equates the actual machine planned time and run time to available time (Demand solutions, 2020).

\subsubsection{Machine reliability}

Machine reliability is the likelihood that machine can perform without failure for a specific period of time and under normal operating conditions. It is the absence of unplanned downtime. For instance a reliable piece of equipment performs like it is supposed to every time you use it (Fiix software, 2020).

\subsubsection{Planned maintenance}

Planned maintenance refers to any maintenance activity at is scheduled and documented. The purpose of planned maintenance is to lessen downtime by having all essential resources available, such as labour and parts, and a strategy to use these resources. There are two types of planned maintenance (Fiix software, 2019).

\section{- Preventive maintenance}

Scheduled maintenance aimed at refurbishing assets before they fail, maintained before any fault occur and maintains a level of certain service on equipment. It protect equipment from sudden breakdown. An example would be conducting maintenance on a CAT machine after every 120 hours of operation.

\section{- Unscheduled maintenance}

Unscheduled maintenance involves putting a strategy in place to repair or replace an asset as quickly as possible when it fails. This requires having sufficient number of easily accessible spare parts on hand to enable a broken one quickly fixed.

\subsubsection{Spare parts}

Generally, a spare part, spare, service part, repair part, or replacement part, is a compatible part kept in an inventory, used for the repair or replacement of failed units. Spare parts are an important feature of maintenance logistics used in productivity and production. Spare part management is to ensure the availability of spares for maintenance in minimum time and reduction in searching time of spares. This requires effective management of spare parts that gives satisfactory results.

Spare parts inventory management involves specifying percentage of stocked goods and it is required at all mine sites for stocking production material. Inventory management needs mining companies to purchase and keep spare parts whilst ordering, shipping, handling, and related costs are checked. It also involves systems and processes that identify inventory requirements, set targets, provide replenishment techniques, report actual, estimated inventory status, and handle all functions related to the tracking and management of material. This includes monitoring of material moved into and out of stockroom locations and the reconciling of the inventory balances (Salunkhe et al, 2019). 


\subsubsection{Workshops}

Globally, underground maintenance facilities are primarily used as a location for service and repair of underground equipment. Underground shops are located in close proximity to operations to enable scheduled maintenance and emergency repairs on production machine run smoothly. Boliden Tara Mines Limited in Ireland owns and operates the largest lead and zinc underground workshop in Europe and one of the largest in the world. The workshop services trackless mining mobile machinery and other fixed equipment components within underground.

\subsection{Mining Auxiliary services}

Mine auxiliary services include productivity issues such tramming ways, road maintenance, compressed air, service water, dewatering and desludging. These issues have indirect or direct impact on mines production.

\subsubsection{Tramming ways}

Mine layouts and schedules involving railways are efficiently planned and equipped, combined with a culture of moving personnel, material, and rock safely, quickly, efficiently and remains a significant factor in future. Rail tracks are well suited for this (Marikana-platinum-mine, 2020).

\subsubsection{Underground mine road maintenance}

Globally, in all mines, road maintenance includes grading and pothole maintenance. Pothole filling is by using wellfragmented rocks or fine chippings from raise boring sites. During road maintenance, the road are compacted and graded. Tactically it is the responsibility of the mineworker to execute road examination and to see the severity of potholes and water buildup on roads and report the road status to the shift bosses, who will delegate works to the team to maintain affected portions.

Roads must be constructed with due consideration for water damage, which is the main cause of road damage in Khutala seam east and west mine in South Africa. A common problem observed was that of roadway water accumulation and water flooding onto the roads. The situation leads to slippery surfaces and that creates the risk of slips and falls and vehicle accidents.

\subsection{CONCLUSIONS AND RECOMMENDATIONS}

Globally, a lot of effort has gone into incorporating improvements and additions that will truly add value in to various unit processes throughout the mining life and helping investors gain the very best results in production. The global mine productivity issues worldwide indicated that reducing various supervisory challenges in mining unit and auxiliary operations together with progress in equipment technology would result in improved productivity and production. Efficient strategic and tactical management plans can also increase productivity of both men and machinery.

\section{REFERENCES}

[1] Carlson software. (2019). Ground deformations. https://www.carlsonsw.com/products/office-software/carlson,accessed, date 02/01/2020

[2] Caterpillar. (2019). Loaders. https://www.epiroc.com/en-jo/products/drill-rigs/surface-blasthole-drill-rigs/pv-351.

[3] Caterpillar. (2019).Third quarter report results.

[4] Caledonia mining. (2020). Operating assets. https://www.caledoniamining.com/operations/blanket-gold-mineoftware.accessed, 14/09/2019.

[5] Clarity visual management. (2020). Standards and systems. https://www.clarityvisualmanagement.com,accessed date, 23/012/2020

[6] Cleverism. (2018).Cognitive development. https://www.cleverism.com, accessed date, 23/02/2020.

[7] Datamine. (2020). Mine management software. http://centricminingsystems.com, accessed date, 23/02/2020.

[8] Daunia Coal Mine, Queensland. (2019). Mining technology. https://www.mining-technology.com/projects/daunia-coal-mine-queensland-australia, accessed date, 02/01/2020

[9] Demand solutions. (2020). Supply chain software 24/7/company. https://www.google.com/search.

[10] Epiroc. (2017). Mining equipment. https://www.epiroc. Com/en-bf/customer-stories, accessed date, 23/012020.

[11] Fine software. (2020). Geotechnical software. https://www.finesoftware.eu/geotechnical-software. Accessed date, 09/12/20.

[12] Fiixsoftware. (2019). Planned-maintenance. https://www.fiixsoftware.com/planned-maintenance.

[13] Granseberg, D.D. (2015).Major equipment life cycle cost analysis, research project report, Institute for Transportation Iowa State University

[14] Geovia. (2020). https://www.g2.com/products/geovia-surpac/reviews, accessed date, 13/02/2020.

[15] Gefasystem. (2020). Aarctic-vent-control).https://www.gefasystem.se/arctic-vent-control.

[16] Goel, S. C. (1986). Implementation of blast hole open stoping using a down-the-hole machine at Nkana. Internal report no. RM56, 04/86, Mineral Resources Development Limited. (https://www.3ds.com/products-services/geovia/products/surpac/) 6 Feb 2020 07:55:26 GMT

[17] Iverson, R. (2019). A new perimeter control blast design concept for underground metal/nonmetal drifting applications investigations report.

[18] Life cycle engineering (2020). Maintenance-Management-Skills-.https://www.lce.com/Maintenance-Management-Skills-511.html,accesed date 25/11/2019.

[19] Lappalainen. E. (1996). Description of the geology of peatiand areas for $t h$ e excursion of the symposium.

[20] Micromine. (2020).3D mine design. https://www.micromine.com/mining grade control, accessed date, 12/20/2020.

[21] MacEwan University. (2020). Management and supervision. https://aboutleaders.com/management and supervision vs leadership. Accessed date, $12 / 20 / 2020$.

[22] Marikina-platinum-mine. (2020).Mining, technology. https://www.mining technology.com/projects/marikana-platinum-mine-rustenburg-south-africa.

[23] Salunkhe. R.T. (2019). Inventory control, ISSN: 2278-1684, PP: 43-47.

[24] Sandvik. 2018. Mining rock technology. Mining rock technology.https://www.rocktechnology.sandvik/en/products/underground-drill-rigs-andbolters/in-the-hole-longhole-drills.acessed date, 12/20/2020.

[25] William, A. (2020). Blasting. www.britannica.com/technology/blasting. Accessed date 12 /20/20.

[26] William, A., and Hustrudlid, W. (2001).Mining Dilution in moderate to narrow width deposits. pp 615.

[27] Whittle, D. (2018). Factors that influence mine design and project value.

[28] Wikipedia. (2019). Dump trucks. https://en.wikipedia.org/wiki/Dump truck. accessed date, 02/01/2019.

[29] Wikipedia. (2020). Productivity. https://en.wikipedia.org/wiki/Productivity . accessed date, 15/01/2019. 